\title{
Research on the Relationship between Management Capability and Corporate Environmental Investment
}

\author{
Hong Li and Ruike Wang a,* \\ School of Management, Tianjin University of Technology, Tianjin 300384, China; \\ a375431035@qq.com
}

Corresponding author: Ruike Wang

Keywords: Corporate Environmental Investment; "U" Type Relationship; Management Capacity.

\begin{abstract}
This paper researched the correlation between the management capability and the corporate environmental investment of enterprise by using the operating data from A-share heavily polluting industry listed companies in Shanghai and Shenzhen (2010-2015). It can be found that: it is a "U" type relationship between the management ability and the corporate environmental investment. This paper is helpful to provide suggestions for environmental governance from the corporate, government and market levels.
\end{abstract}

\section{Introduction}

Environmental problems are urgent problems to be solved. Environmental industry investment is the key to improve the environment. According to the statistics of the relevant environmental protection departments, the environmental pollution caused by the production and operation of the enterprises is as high as $80 \%$ [1]. As the energy consumption and the manufacturer of environmental pollution, the enterprise cannot shirk its responsibility for environmental pollution control. Senior management as the main human resources, largely control the capital investment, the strength of management ability is directly related to the enterprise environmental investment decision. Management will be different because of the ability of the enterprise environmental investment performance for different strategies, thereby affecting the entire capital investment efficiency of the enterprise, and then affect the economic benefits of enterprises. In this paper, the management ability as a starting point, in-depth exploration of the management of enterprise environmental investment decisions.

\section{Theoretical analysis and Hypothesis}

Strategic choice would be made according to the personal awareness and values of management due to their limited rationality [2]. Management capacity as a comprehensive reflection of cognition and values, directly determines the management behavior [3]. The enterprise environmental investment is not only the behavior to pursuit corporate economic interests of the management, but the behavior to perform social responsibility, so it is difficult to do completely rational for management. According to Maslow's hierarchy of needs, management will achieve its own needs from low to high. Management will give priority to their own interests before the target to meet certain conditions. As the environmental protection investment is a coordinated and sustainable development investment activity which unified environmental benefits, social benefits and economic benefits in a whole, while environmental protection investment has a high opportunity cost, managers will put the economic benefits in the first place before the enterprise production efficiency reached a certain level. Through the data, Li Qiang (2016) said that companies focus on financial performance when the production efficiency is relatively low, and senior managers will be resistant to the investment of environmental protection [4]. Therefore, the management capacity and enterprise environmental investment scale has a negative correlation with the continuous improvement of production efficiency before the enterprise production efficiency reach a certain level. 
When the production efficiency reaches a certain level of production, in ensuring the economic benefits of the premise, the management begin to pay more attention to social and environmental benefits of enterprise that is the enterprise will increase the scale of environmental investment. From the perspective of the reputation mechanism, the reputation can generate incentives and constraints of the management behavior. Under the guidance of the policy of ecological and environmental issues in the whole country and the premise of guaranteeing economic interests, the management will invest or increase the scale of investment of environmental protection. This not only improve their reputation in the competitive market, but improve their income and meet their own deep-level needs. Therefore, when the enterprise production efficiency reaches a certain level, the management capacity and enterprise environmental investment scale have a positive relationship.

In summary, the management capacity is not linear with the enterprise environmental protection investment. This paper proposes a hypothesis $\mathrm{H} 1$.

H1: In other factors remain unchanged, the management capacity and corporate environmental investment scale was "U" type relationship.

\section{Research Design}

\subsection{Sample Selection.}

According to the 2010 Ministry of Environmental Protection issued a "listed company environmental information disclosure guidelines (draft)" and the wind database in the SFC industry class division, defining the heavily polluting industries, this article based on A-share heavily polluting industry listed companies in Shanghai and Shenzhen (2010-2015) as research sample, the sample was screened on the basis of the following conditions: (1) excluding sample companies of ST, PT, SST *; (2) to exclude the listed companies that have never disclosed the environmental protection investment in China from 2010 to 2015; (3) excluding companies that calculate the lack of management capacity data; (4) remove the other variables missing companies. After screening, this article received a total of 366 samples from 114 companies.

\subsection{Variable Definition.}

\subsubsection{The Corporate Environmental Investment.}

In order to avoid the impact of the scale of enterprises on the scale of environmental investment, the choice of "total investment in environmental protection of enterprises/capital stock" is used to measure the level of environmental protection investment in enterprises. The total investment in environmental protection of enterprises is defined according to the environmental management system certification (ISO 14001), and the capital stock takes the arithmetic average of the total assets at the beginning of the year and the total assets at the end of the year as the index of capital stock. Which is:

Enterprise environmental protection investment (EPI) =total investment in environmental protection *

2 / (total assets at the beginning of the year + total assets at the end of the year)

\subsubsection{The Management Capability.}

For the measurement of managerial competency, this paper uses a generally accepted Demarion (2012) data envelopment analysis (DEA) to measure management capacity [6], The specific steps are as follows:

First, the use of data envelopment analysis to estimate the production efficiency $(\theta)$. The DEA model is a model for evaluating the efficiency of the input and output variables. All firms invest in financial capital, labor capital and various technological innovation capital, with income as the final form of output. DEA optimal model as shown in Equation 2:

$$
\max _{v} \theta=\frac{\text { Sales }}{V_{1} P P E+V_{2} \text { Net } R \& D+V_{3} \text { Goodwi } 11+V_{4} \text { In tan }+V_{5} C o G S+V_{6} S G \& A}
$$

Sales: operating income; PPE: net fixed assets; Net $R \& D$ : enterprise net development costs; Intan: intangible assets; $C o G S$ : the cost of sales; $S G \& A$ : business management, marketing costs; production 
efficiency between 0 and 1 , when the enterprise production efficiency is optimal, $\theta$ is 1 , the enterprise can reduce costs or increase sales revenue to achieve optimal production efficiency.

Second, the estimated management capacity (MA). Although the production efficiency can be used as the proxy variable of management ability, but the enterprise production efficiency is also affected by other aspects of the enterprise level, this paper used Tobin regression on the production efficiency of enterprises, and selected the 6 production efficiency of the enterprise level factors, namely Enterprise size, market share, free cash flow, age of business, diversification and corporate property rights. Create a model as shown in Equation 3:

$\theta=\alpha_{0}+\alpha_{1}$ Size $+\alpha_{2} M S+\alpha_{3} F C F+\alpha_{4} A g e+\alpha_{5} D i v+\alpha_{6}$ Nature $+\varepsilon$

Among them, the residual value $\varepsilon$ obtained by the model regression is the management ability.

\subsubsection{Other Variables.}

In this paper, on the basis of the existing literature, we add the control variables that affect the enterprise's environmental protection investment. The specific variables and definitions are listed in table 1.

Table 1. Variable definition table

\begin{tabular}{|c|c|c|c|}
\hline & ariable type & Variable symbol & Variable description \\
\hline \multicolumn{2}{|c|}{$\begin{array}{c}\text { The corporate environmental } \\
\text { investment }\end{array}$} & EPI & Specific definitions see above \\
\hline \multicolumn{2}{|c|}{ The management capability } & MA & Specific definitions see above \\
\hline \multirow{7}{*}{$\begin{array}{l}\text { control } \\
\text { variable }\end{array}$} & Operating cash flow & Flow & Operating cash flow / total assets \\
\hline & Cash holding & Cash & Year-end currency funds holding / total assets \\
\hline & $\begin{array}{c}\text { Investment } \\
\text { Opportunities }\end{array}$ & Opp & Expressed as Tobin'Q value \\
\hline & Financial Leverage & FL & Assets and liabilities \\
\hline & Enterprise scale & Size & The natural logarithm of the total assets of the firm \\
\hline & Profitabilitv & $\mathrm{ROA}$ & Roa \\
\hline & Time & Year & Virtual variables, from 2010 to 2015 were assigned 1-6. \\
\hline
\end{tabular}

\subsection{Model Building}

In order to validate the assumption presented in this paper, the basic regression model is established as follows:

$$
\begin{aligned}
E P I_{i, t}=\alpha_{0} & +\alpha_{1} M_{i, t}+\alpha_{2} M A_{i, t}^{2}+\alpha_{3} \text { Flow }_{i, t}+\alpha_{4} \text { CaSh }_{i, t}+\alpha_{5} \mathrm{Opp}_{\mathrm{i}, \mathrm{t}}+\alpha_{6} \mathrm{FL}_{i, t}+\alpha_{7} \text { Size }_{i, t} \\
& +\alpha_{8} \text { ROA }_{i, t}+\alpha_{8} \text { Year }_{i, t}+\varepsilon
\end{aligned}
$$

\section{Empirical Results and Analysis}

\subsection{Descriptive Statistics.}

As shown in table 2, more than half of the sample of environmental protection investment in the scale of less than $0.6 \%$, while the maximum and minimum were $0.001 \%, 19.2 \%$, the gap between the great, indicating that China's listed companies on environmental there is a general lack of investment, while the difference between the size of investment. The total management capacity of the sample is 0.046 , the mean is 0.0001 , indicating that inefficient management accounts for the majority. 
Table 2. Descriptive statistics of variables

\begin{tabular}{|c|c|c|c|c|c|}
\hline \multirow{2}{*}{ Variables } & \multicolumn{5}{|c|}{ Sample } \\
\cline { 2 - 6 } & $\mathrm{N}$ & median & Mean & minimum & maximum \\
\hline EPI & 366 & 0.002 & 0.006 & 0.00001 & 0.192 \\
\hline MA & 366 & 0.046 & 0.001 & -0.3586 & 0.141 \\
\hline HHI & 366 & 0.071 & 0.102 & 0.0185 & 1.000 \\
\hline Flow & 366 & 0.057 & 0.062 & -0.1526 & 0.407 \\
\hline Cash & 366 & 0.123 & 0.152 & 0.0089 & 0.615 \\
\hline Opp & 366 & 1.699 & 2.172 & 0.8423 & 15.654 \\
\hline FL & 366 & 0.529 & 0.493 & 0.0415 & 0.948 \\
\hline Size & 366 & 13.998 & 14.01 & 11.1966 & 16.699 \\
\hline ROA & 366 & 0.062 & 0.077 & -0.196 & 0.387 \\
\hline
\end{tabular}

\subsection{Regression Analysis.}

The results of the regression analysis are shown in Table 3. The square of managerial competence is positively correlated with the scale of environmental investment, and all of them have a positive correlation with $1 \%$ significance level, which shows that the enterprise's production efficiency is improving, the decision-making performance of the enterprise's investment in environmental protection is reduced first and then increased. In other factors remain unchanged, the management capacity and corporate environmental investment scale showed "U" type relationship. The relationship between the scale of environmental protection investment and management capacity has a critical value. Before the threshold value, the management capacity is negatively correlated with the environmental investment. After the threshold value, the management capacity is positively correlated with the environmental investment. Assume that $\mathrm{H} 1$ is validated.

Table 3. Regression results

\begin{tabular}{|c|c|c|c|c|c|c|c|c|c|c|c|}
\hline variable & MA & MA2 & Flow & Cash & Opp & FL & Size & ROA & Year & R2 & $\begin{array}{c}\text { P } \\
\text { value }\end{array}$ \\
\hline Coefficients & 0.012 & $0.550^{* * *}$ & $0.048^{* * *}$ & $0.024 * *$ & 0.0001 & $0.024 * * *$ & $-0.002 * *$ & $-0.055^{* *}$ & 0.000 & \multirow{2}{*}{0.48} & 28.47 \\
\cline { 1 - 7 } T value & 1.182 & 8.334 & 3.395 & 2.506 & 0.163 & 4.017 & -2.5700 & -4.368 & 0.006 & & \\
\hline
\end{tabular}

Note: $* * *, * *, *$ are representative at $1 \%, 5 \%, 10 \%$ level significantly.

\section{Summary}

This paper shows that the enterprise management capacity has an impact on the scale of enterprise environmental investment. Overall, the enterprise management capacity and the scale of enterprise environmental investment are " $U$ " type relationship. In view of the above research, the following countermeasures and suggestions are put forward: (1) Establishing and improving the enterprise environmental information disclosure mechanism and improving the enterprise environmental awareness. (2) The government should strengthen the supervision of environmental protection, restrict the enterprise from the legal level, and formulate the enterprise environmental protection policy. (3) Warning of the enterprise environmental investment is one of the elements of competition between industries, especially private enterprises. (4) Management should take the lead in raising awareness of environmental protection, environmental training for employees to form a corporate culture.

\section{References}

[1]. Shen Hongbo, Xie Yue, Chen Zhengrong. Enterprise environmental protection, social responsibility and market effect, Chinese industrial economy, a case study of Zijin mining pollution incident based on [J]. 2012 (01): 141-151. 
[2]. Hambrick D. C., Mason P. A. Upper Echelons: The Organization as a Reflection of its Top Managers [J]. Academy of Management Review, 1984, 9(2): 193-206.

[3]. Zhang Dunli, Jiang Xinfeng. Management ability and enterprise investment herding behavior: the role of [J]. In regulation of compensation fairness based on accounting research, 2015, (8): 41-48.

[4]. Li Qiang, Tian Bi, Liu Tong. The influence of the political network of senior executives on the environmental protection investment of enterprises: considering the role of government and market [J]. Journal of Shanxi University of Finance and Economics, 2016, (3): 90-99.

[5]. Demerjian, P., B. Lev, \& S. McVay. 2012. Quantifying managerial ability: a new measure and validation tests. Managerial Science, 58(7): 1229-1248. 